\title{
JĀNIS KRISTAPSONS (23 JUNE 1939 - 26 APRIL 2017), LATVIAN PHYSICIST AND SCIENCE ORGANISATOR
}

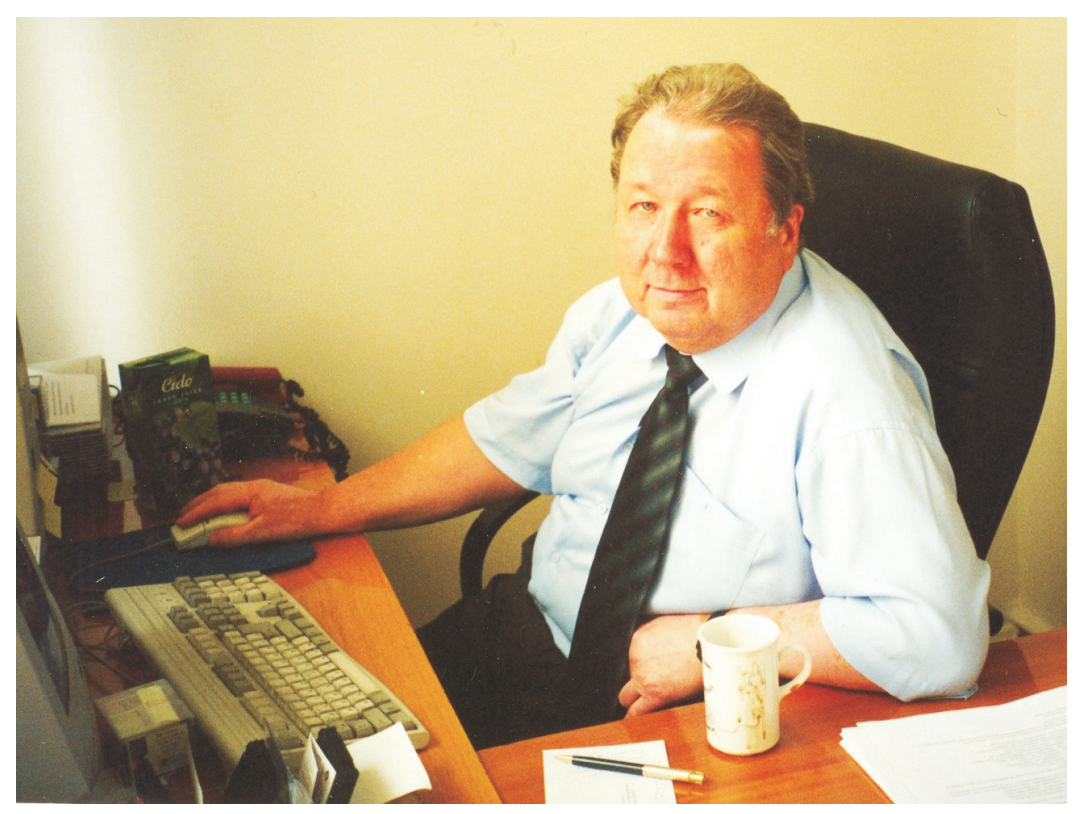

Dr. phys. Jānis Kristapsons passed away on 26 April 2017. He was a corresponding member of the Latvian Academy of Sciences (since 1995) and an outstanding science organiser and researcher at the Latvian Academy of Sciences.

Jānis Kristapsons graduated from the Faculty of Physics and Mathematics, State University of Latvia (now University of Latvia) (1962) in nuclear physics (supervised by Kurt Schwarz). He defended his Doctoral Thesis in Physics (1971) "Alkaline halide crystal radiation in colloidal colour spectrum". He did research on materials necessary for the hologram records. In 1976, he published a monograph $O p$ tically Reacting Materials (together with K. Schwarz and V. Gottlieb).

His research interests were related to organisation of scientific information, general science research and scientology. He was the head of the Department of Scientifically Technical Information at the Institute of Physics (1973-1981).

At the Latvian Academy of Sciences, J. Kristapsons was a senior researcher, Head of the Department of Science Information, and Scientific Secretary (1972-1981), and later he became a Deputy Chairman at the Science Information Council (1975-1989) and deputy Scientific Secretary (1982-1992).

During 1989-1992, J. Kristapsons actively participated in the initiating, preparation, and realisation of science reforms in Latvia. He was one of the members of the Latvian Science Association and Committee of the Academy of Sciences who had developed the principles and had elaborated the draft decisions on science funding and system of leadership. He had also participated in the establishment of the Latvian Science Council, and in the development of draft law "On scientific activity".

J. Kristapsons worked at the Academy of Sciences as an Advisor to the President of the Academy (1992-2014), as a member of the Editorial Board of the journal Proceedings of the Latvian Academy of Sciences and Zinātnes Vēstnesis, and as an author for those editions. He had established the Scientometrics Research Group and was its head in 1991-2002. Together with his research group, he studied research indicators, research policy, indicators of innovative indicators, innovation policy etc.

The main achievements of J. Kristapsons and his team was the development of the electronic database on Latvian researchers, innovators, and innovations, research on the productivity of research and technologies (publications, innovations, patents in Latvia and abroad).

He was a dedicated researcher and worked on the analyses of the transformation of research and technology after 1990. In 2001, together with J. Ekmanis, he prepared and presented a lecture "Science of Latvia: an overview of 1990-2000" at the Plenary Session of the World Congress 
of Latvian Scientists. He is a co-author of the book Baltic $R \& D$ Systems in Transition. Experiences and Future Prospects? (2000, Stockholm: Sodertorns Hoghskola; 2003, Zinātne, Rīga).

J. Kristapsons is an author of more than 20 publications books and articles. One of his most prominent publications is The Analytical Report on Innovation Policy in Latvia (2002)

J. Kristapsons was a person expressing precise and original opinion on the topical issues on science in Latvia. He actively participated in the reform process of the Latvian Academy of Sciences in the 1990s. He had his input in the development of the Charter of the Academy and, for more than 20 years, in the development and writing of Academy Yearbook. In 2002, he had initiated the idea about the annual national nomination on the research achievements, which was implemented.

In 2002, J. Kristapsons was awarded the prize of the Academy of Sciences and JSC Grindex for essential investment into the research of the Latvian science and technology potential. In 2003, he received the Medal of the Baltic Academies of Sciences for his contribution in science transformation in Latvia and support to the cooperation between the Baltic Science Academies.

Jānis Stradiňš

\section{JĀNIS KRISTAPSONS (1939-2017), FIZIK̦IS UN ZINĀTNES ORGANIZATORS}

2017. g. 26. aprīlī mūžības ceḷos devies Latvijas Zinātnu akadēmijas (LZA) korespondētājloceklis Dr. phys. Jānis Kristapsons — izcils LZA darbinieks un zinātnes organizators.

Jānis Kristapsons absolvējis LU Fizikas un matemātikas fakultāti (1962) (specialitāte — kodolfizikis). Strādājis Fizikas institūta Kodolreaktorā, jonu kristālu radiācijas fizikas laboratorijā (1962-1971) (vadītājs — profesors Kurts Švarcs). 1971. gadā aizstāvējis kandidāta (fizikas doktora) disertāciju "Sārmu halogenīdu kristālu radiācijas koloidālie krāsu centrì". Vēlāk pētījis materiālus hologrammu ieraksta vajadzībām. Kopā ar K. Švarcu un V. Gotlību sarakstījis monogrāfiju Optiskie reǵistrējošie materiāli (1976).

No 1989. līdz 1992. gadam J. Kristapsons aktīvi piedalījās Latvijas zinātnes reformu sagatavošanā un realizācijā — bija viens no Latvijas Zinātnieku savienības un LZA komisijas locekḷiem, kas izstrādā principus un sagatavo lēmuma projektu par zinātnes finansēšanas un vadības sistēmas izmaināām Latvijā un Latvijas Zinātnes padomes nodibināšanu, kā arī piedalījās likumprojekta "Par zinātnisko darbību" izstrādē. Līdz pat 2014. gadam J. Kristapsons strādāja Latvijas Zinātnuu akadēmijā, ieṇemdams LZA prezidenta padomnieka amatu (no 1992. gada); darbojās arī žurnāla LZA Vēstis un laikraksta Zinātnes Vèstnesis redkolēǵijāās, arī kā rakstu autors. 2002. gadā J. Kristapsons saṇēma LZA un AS "Grindeks" balvu par nozīmīgu ieguldījumu Latvijas zinātnes un tehnoloǵiju potenciāla izpētē un popularizēšanā, bet 2003. gadā tika apbalvots ar Baltijas zinātṇu akadēmiju medaḷu par nopelniem zinātnes transformācijas izpētē Latvijā un Baltijas zinātṇu akadēmiju sadarbības veicināšanu. 